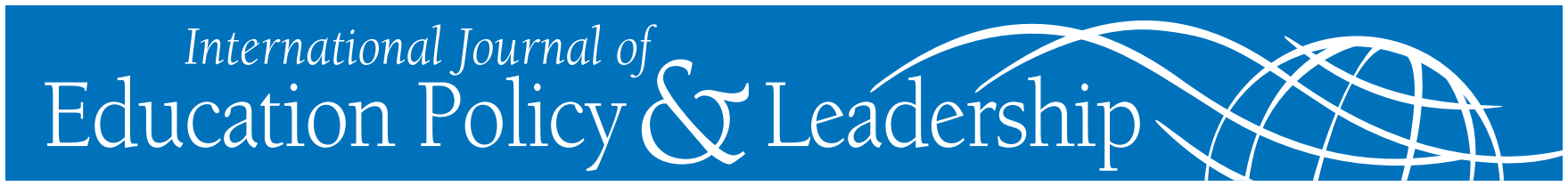

\title{
Teachers' Pastoral Role in Response to the Needs of Orphaned Learners
}

\author{
Teresa Auma Ogina \\ University of Pretoria
}

\begin{abstract}
This article discusses a study that explored the way teachers perceive and describe their roles in responding to the needs of orphaned learners. The participants in the study comprised three secondary and two primary school teachers. The data on the teachers' experiences were collected through semi-structured interviews, and the findings revealed that, although some of the teachers attempted to fulfill some of the orphaned learners' needs, most were unable to cope with the combined roles of teaching and learning and care giving. The study identified a lack of material, social, and emotional support for grieving learners. The findings indicate that there is a need for teacher development in terms of preparing teachers to provide pastoral care for orphaned learners. For the teachers' efforts to be more fruitful, there is also an urgent need for supportive school leadership. In addition, the study highlights the need for counsellors and social workers to be appointed to work in collaboration with the teachers in providing for the needs of the learners.
\end{abstract}

Ogina, T. A. (2010). Teachers' Pastoral Role in Response to the Needs of Orphaned Learners. International Journal of Education Policy and Leadership 5(12). Retrieved [Date] from http://www.ijepl.org.

\section{Introduction}

A growing body of literature indicates that childheaded families and orphanhood are becoming common phenomena in many African countries as a result of the increased death rate among young parents (Makame, Ani, \& Grantham-McGregory, 2002; Nyambedha, Wandibba, \& Aagaard-Hansen, 2003; Abebe \& Aase, 2007; Cluver \& Gardner, 2007; Kidman, Petrow, \& Heymann, 2007; Oleke et al., 2007; Van Wyk \& Lemmer, 2007; Robson \& Kanyanta, 2007; Taylor \& Kvalsvig, 2008; Thurman et al., 2008). It has been estimated that 14 million children have been orphaned by HIV/AIDS, the majority (95 percent) in subSaharan Africa (UNAIDS, 2004). The increasing number of orphans in most African countries presents certain challenges. Parents are generally the ones who fulfill their children's physical, social, and psychologi- cal needs, such as providing love, affection, and a sense of belonging (Berger, 2000; USAID, 2000).

Furthermore, parents play a supportive role in their children's learning experiences (Epstein, 2001; Jarolimek, Foster, \& Kellough, 2001); when a child is orphaned, the child's support structure and learning experiences may suffer. Some studies (Makame et al., 2002; Nyambedha et al., 2003; Chitiyo, Changara, \& Chitiyo, 2008) have described children without parents as being vulnerable and usually traumatized by their parents' death, which is often followed by a change in their living conditions. Some studies (Cluver et al., 2007; Foster \& Williamson, 2000; Giese, Meintjes, Croke, \& Chamberlain, 2003; Robson \& Sylvester, 2007; SCOPE-OVC/Zambia, 2003; Van Wyk \& Lemmer, 2007) have described children without parents as being vulnerable and often traumatized by their parents' death and the change in their living conditions that frequently follows. Removing children from

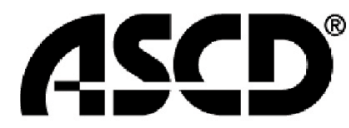

LEARN. TEACH. LEAD.
SIMON FRASER UNIVERSITY THINKING OF THE WORLD

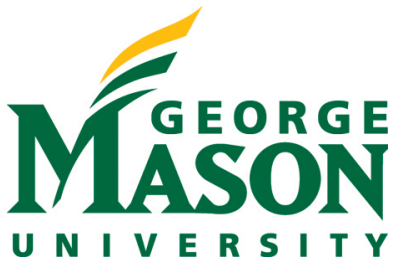


the residences and situations with which they are familiar can cause them to be deprived of material and psychological support. Addressing some of these concerns is necessary to ensure that these children gain the full benefits of their educational experiences.

Increasingly, teachers and schools in most African countries are expected to respond to the changing educational, social, and economic environment and the contextual realities of schooling, and that includes caring for the orphaned learners. The South African Department of Education Norms and Standards for Educators (2000) stipulate pastoral role as one of the seven roles of an educator. Despite the expectation of a caregiving role, the way in which teachers understand their role in terms of pastoral care and their willingness and readiness to take up this role remain under researched (Schierhout et al., 2004). This is even more evident when it comes to caring for orphans (McBride, 2002). No known studies have examined the role that teachers play in caring for orphans in the context described in this study. The purpose of this article is to explore the role that teachers play and the support provided by the school principals in providing for some of the orphaned learners' needs, based on the experiences of the five teachers interviewed.

\section{Care for the Orphans}

Several researchers (Urassa, Boerma, Ng'weshemi, Isingo, Schapink, \& Kumogola, 1997; Foster \& Williamson, 2000 Nyambedha et al., 2003; Oleke et al., 2007) have noted that, in most African countries, including South Africa, the extended family and community continue to care for most orphans especially in rural areas. However, more recent studies on orphan care in Africa have revealed that the extended family networks are becoming weaker as both the number of orphans and the mortality rate among adults increase (Foster \& Williamson, 2000; Beard, 2005; Freeman \& Nkomo, 2006; Kidman et al., 2007; Heymann et al., 2007; Van Wyk \& Lemmer, 2007). In addition, extended family members seem increasingly unable to balance meeting the orphans' need for essential care with working to survive economically. A survey carried out by Heymann and others (2007) on the way extended families balance their work with providing orphans with care revealed that nearly half of the extended families in the study had difficulty in meeting the orphans' needs in addition to those of their own children owing to the demands of their work, and lack of time and material resources.

Numerous studies have recognized the role that the school could play in providing care for the orphans in the absence of family support (USAID, 2001; McBride, 2002; Giese et al., 2003; Richter, 2003; Loots \& Mnguni, 2006; Van Wyk \& Lemmer, 2007), yet these studies inadequately address the role of teachers as caregivers and the conflict that ensues when attempting to combine the role of providing care with that of teaching and learning. The assumption underpinning this study is based on the views of Epstein (2002) and Miller (1990), who theorized that, in educating a child, one cannot separate the emotional and social factors from cognitive factors. It implies that during the teaching and learning process teachers are expected to be able to deal with the intellectual, emotional, and social aspects of a child's development. Zappulla (1997) and Van Wyk and Lemmer (2007) suggest that, in cases of orphanhood, teachers may be the only adults to whom the orphans can turn for the fulfillment of the needs normally met by parents. Moreover, "Teachers are in contact with the learners throughout their working day and often have to deal with problems when they arise and not wait for specialist help" (Cleave, Carey, Norris, Sloper, While, \& Charlton, 1999:16). Hence, the need for pastoral care becomes crucial in schools with orphans who are experiencing the absence of parental care and unfulfilled needs.

Pastoral care is not a separate activity; rather, it is part of teaching practice, which recognizes that intellectual and social development cannot be accomplished without taking account of both internal factors (personality, character, and emotions) and external factors (society and environment) (Best, 2007). The South African Department of Education Norms and Standards (2000) identify seven roles for the teacher and the competencies within each role. The community, citizenship, and pastoral role requires teachers to "demonstrate the ability to develop a supportive and empowering environment for the learner and respond to the educational and other needs of learners and fellow teachers." The practical competencies of the pastoral role include demonstrating care, protection, and the holistic development of the child. Despite the fact that the Norms and Standards stipulate pastoral care as 
an important teacher role, teachers' caring support in response to the needs of orphaned learners remains under researched (Schierhout, Kinghorn, Govender, Mungani \& Morely, 2004).

\section{Contextualizing the Study}

This article is based on data collected for a doctoral study from five female teachers between the ages of 35 and 45 who were purposely chosen by means of a snowballing process. The process involved interviewing one teacher, who then recommended another teacher to be interviewed, and so on. The teachers involved in the study were known by other teachers to be involved with orphaned learners. Two participants were drawn from a primary school with 112 orphaned learners and three from a secondary school with 126 orphaned learners. The two schools are in a rural area of Mpumalanga province in South Africa. According to the teachers interviewed, the mortality rate in the community is high. A 2000 antenatal survey (South Africa HIV \& AIDS Statistics Summary, Department of Water Affairs, 2007) reported the HIV/AIDS prevalence in Mpumalanga to be the second highest in South Africa (29.2 percent). Most learners in this area come from households with an annual income of less than R18,000 (State of Environment in South Africa Mpumalanga - Poverty and Vulnerability, 2005). Other poverty indicators are unemployment and a lack of basic facilities such as sanitation, electrification, and water.

\section{Method}

I used face-to-face, in-depth interviews and follow-up interview questions to collect data on the ways in which teachers describe their role in responding to the needs of orphaned learners. In the initial interviews, I asked teachers to talk about themselves and their experiences with the orphans and asked the following questions, among others: How do they identify the orphans? Do the orphans talk about their experiences or not? What do teachers do when the learners tell them about their needs? Do school principals and other teachers become involved in helping orphaned learners? The questions were open-ended to elicit the teachers' perceptions and stories of their experiences. I interviewed each participant twice for approximately
45 minutes to one hour. In the second interview, I asked the participants questions based on the themes that emerged from the first interview. I conducted follow-up interviews to verify and clarify the data. The interviews were tape-recorded and transcribed. The verbatim transcripts produced from the interviews were coded and the codes grouped into categories. From these categories a number of themes emerged, including identifying the needs of orphaned learners, teachers' perceptions of their roles, role conflict, and the perceptions of leadership involvement in managing the orphans' needs. The teachers who were interviewed were given interview transcripts and the emerging themes to verify the accuracy of the data and the interpretation. Transcripts of data analysis were also peer reviewed to verify the data's integrity.

\section{Results}

\section{Identifying the needs of orphaned learn- ers}

Most of the teachers interviewed identified food, school uniforms, and money to pay for school requirements as being the learners' most basic needs. One secondary school teacher described the situation:

When I arrived in this school, I noticed that during break a lot of the kids were not eating and after break others were playing truant. When I tried to find out why they were not at school after break, I discovered that most of them were hungry. This finding is consistent with the finding of De Witt and Lessing's 2005 report derived from their quantitative study using questionnaires administered to 120 teachers from a number of different schools. Their findings revealed that lack of food and clothing was the most pressing problem. However, emotional needs are not as visible as material needs, and teachers in the study done by De witt and Lessing (2005) revealed that they struggled to identify the orphaned learners' emotional needs and had to rely on what the learners tell them.

Unfortunately, not all learners are willing to talk to teachers about their experiences, perhaps as a result of the stigma and discrimination associated with HIV/AIDS-related death. The case study of Chitiyo and others (2008) on psychological support for children orphaned by AIDS reported that all the children 
in the study showed signs of emotional deprivation that affected their learning. Providing orphans with emotional support seemed to be a challenging task for the teachers in the current study. One of the teachers explained as follows:

There is only one that I know who is very sensitive about it. I think that reason is that it is not too long since ( she was) orphaned. She is still feeling it just as raw as it is. The others most of them were orphaned at an early stage, when they were still not aware of what life is. They had to accept the fact that they do not have parents and granny is taking care of them. In fact all of them are not acknowledging it. They are trying to keep it inside. They try hard to be like other learners, in fact that is what we emphasize to them.

The extract suggests that the teachers understand the grieving process to be a temporary emotional state. The fact that the learners are being encouraged to hide their emotions may mean that the teacher is attempting to avoid exposing them to further trauma if other learners stigmatize them. A study conducted in northern Uganda on the constraints to orphans' educational opportunities reported that teachers interviewed were of the opinion that providing special support for orphans in school could foster stigmatization (Oleke, Blystad, Fylkesnes, \& Tumwine, 2007). Another possible explanation of the teachers' response could be a lack of emotional capability to support the learners. Abebe and Aase (2007) describe emotional capability as the willingness and the ability of a caregiver to give psychological and emotional support. In relation to the orphaned learners' emotional needs, several of the teachers in the current study indicated that a number of orphans had behavioral problems. The following narration illustrates this viewpoint:

Some become violent. Maybe you find that their friends are teasing them when they are playing. They will take the teasing seriously. It seems that there is anger inside them. So, when they start teasing, the learner will react violently and automatically somebody will have some blood moving out of the body.

Grieving children's emotional outbursts are not unique to this study; in another study, Willis (2002) identifies withdrawal and violent behavior as common signs of mourning. This finding indicates that some of the orphans in this study could still be mourning their parent or parents' death, which would explain the cause of the violent behavior. The findings of a study on barriers to the community support of orphans and vulnerable youth in Rwanda also reported that community members perceived orphans as troublemakers, describing their behavior as unruly and disruptive (Thurman, Snider, Boris, Kalisa, Nyirazinyoye, \& Brown, 2008). Dowdney (2002) agrees with this finding and reported that one in five bereaved children is likely to manifest emotional and behavioral symptoms in the form of anxiety, depression, anger, outbursts, and regression.

\section{Role of teachers}

The teachers interviewed perceived their roles in different ways. One of the teachers felt that the role of providing care should be the government's responsibility. She said:

I would prefer that somebody give them food and pay school funds for them. I think the Social Welfare Department should see to such kids.

Another teacher indicated that caring for the orphaned learners is not the responsibility of teachers per se, but the choice of the individual teacher. She thought that the school system does not endorse care for orphaned learners as part of teachers' responsibilities and further argued that, as a result of individual differences, some teachers were more compassionate toward the orphans than others. The teacher explained:

I think that the other teachers don't want to be involved because they just feel that it is not their problem. This is not really part of what we should be doing. It is what you feel. When you are at home and you are eating and there is food that is left and you know what is happening out there, it troubles my heart. That is why you go out to help. This is not a feeling everybody has, so you cannot condemn those who do not help.

In contrast, another teacher perceived the role of providing care as the responsibility of all teachers. She appeared to ascribe the lack of teachers' response to the needs of the learners to a lack of dedication. She felt that she was being exploited by other teachers who were prepared to let her take responsibility and she challenged them to be more responsive in providing care. 
Learners come to me. It became my job. I do not feel pain, I do not ask for contribution from the other teachers. Other teachers when it comes to the problem of orphaned learners they push the orphans to me. "Go to Teacher Khumalo, she will help you." I asked, "Why can't you help; why do you always send the learners to me?"

Owing to the differing perceptions of the role of providing care, the teachers' commitment to this task varies. Some teachers provide food, clothes, and emotional support through guidance and counseling. One of the teachers told how she responded to the needs of a sexually abused learner by facilitating assistance from different role players, such as a medical practitioner, a social worker, a counselor, and a policewoman. She said:

The cousin raped the girl. So I called the girl and asked her whether she has been taken to the doctor. The guardian took the girl to the doctor and only asked for painkillers. I phoned the doctor and the doctor told me to take the learner to the hospital. The doctor examined the girl and she was safe. We remained convinced that the girl must be counseled [and] go through therapy because when she is quiet the things come back to haunt her. So I approached the hospital; they said that they need a docket number. So I took the girl to the police station to get the docket number. Thereafter is when the girl got attention from Social Welfare.

Other teachers responded to the needs of the orphaned learners by referring the learners to a third party for help. Two teachers reported the following:

I send them to the teachers who help orphans. The social workers usually say that we must send a list of the learners that we have here to them. We did send the list but they did not respond.

As a class teacher I have to report this to those who help the orphans like Ms. Chabalala. She does it by giving them money to buy bread and soup during break.

This quote reveals that not all teachers are involved in helping orphaned learners-those who are committed seem to be internally motivated to do so. For example, one teacher's background experiences and religious beliefs motivated her to help the orphans. She said:
I am from a poor background. When I used to go to school the teachers would buy for me the things that I did not have, like school uniform and books. I am also a Christian and I like to help people when I can. This is why I ask learners about their problems.

Another teacher also had a positive attitude towards helping orphaned learners, saying:

Every year I would buy uniform for one learner. I think I got it from my mother. When she was still alive she used to help learners.

It seems that when the two teachers reflected on their background, they were able to relate to the orphaned learners' experiences and empathize with them. The literature reports that compassion is the key underlying factor to an individual act of kindness and care towards others (Foster \& Williamson, 2000).

\section{Role conflict}

The teachers' experiences indicate conflict in the interpersonal relationships between the teachers and conflict in the teachers' duties and responsibilities. The differences in the perceptions of the teachers' role and their responsibility for providing orphaned learners with care in particular appear to be causing tension and conflict. One of the teachers, for example, explained:

As teachers, we have to be social workers, parents, and everything. I had to come quickly just before lunch and prepare the soup and bread for the learners on the day they have soup and bread. I had to leave class before time and leave them with work. I knew that it was not right but now the lady who works as a general worker helps me.

Another teacher said:

You know I am teaching at the same time I am dealing with the orphans at the same time I am a policewoman. I am a social worker and a counselor.

As evidenced by this study, the emerging multiple roles of teaching and caregiving are in agreement with the findings of Schierhout et al. (2004), who reported that teachers perceive their roles as encouraging learners to attend school, and providing food, counseling and advice, money, and school fees.

As indicated in the quotes, from the two teachers' experiences it would seem that these multiple roles are 
demanding and that it is probably unrealistic to expect them to be taken on unless, as Evans (2002) suggests, teachers' roles are modified and redefined to include caring for learners' social and emotional needs. The new role definition would then imply a supportive structure that would enable teachers to carry out their responsibilities more effectively and less stressfully.

\section{Teachers' perceptions of the involvement of the school principals in supporting the teachers' pastoral role}

Another emerging theme from the study is the leadership role of the school management in responding to the needs of orphaned learners. From the teachers' responses it seems that school management, specifically the principals at the two schools investigated, were not directly involved in providing for the needs of the orphaned learners. At times they supported the efforts that some of the teachers made in providing for the learners' needs, but these efforts had to be on the teachers' own initiative. In one case, for example, one teacher commented that the principal had encouraged and supported her efforts to assist the orphans. She stated:

If you go to the principal and tell her that you want to help an orphan, she does not block your efforts; she encourages you to go ahead. Like when I was telling you that I had to come before break to prepare the lunch for the learners. I was never hassled about it. They understood that I had to do it. When the general worker came in, I asked the principal to include in her job description that the worker should help with this and the principal did it.

However, another teacher experienced a conflict of interest with the school management regarding the use of donations received to support the learners. The teacher wanted to use the donated money to provide food and school uniforms for the orphans, while the school principal's suggestion was to improve the school' infrastructure. The teacher explained:

When I told my principal that I got donations from the university for the orphans, she said that I must use the donations for buying computers and paving the school. But this is not the job I want to do.
It appears that there is a need for supportive and caring leadership that encourages teachers to become involved and respond positively to the orphans' needs. The two teachers' experiences suggest uncertainty about the school management's role in providing assistance for orphaned learners and the lack of a support structure.

Time constraints and the lack of teacher capacity to provide for the orphans' needs in the absence of material and human resources seem to make it more challenging for teachers to provide pastoral care for traumatized, grieving children at school. All the teachers interviewed acknowledged this problem and recommended that alternative care in the form of an orphanage should be considered to provide holistically for the orphaned learners.

\section{Discussion}

The results of this study indicate that teachers identified the needs of the orphaned learners as being material, social, and emotional. The emotional needs were more difficult to identify and more challenging to fulfill. Teachers are considered to be frontline workers in recognizing the danger signs in learners and responding immediately and effectively to them (Cleave et al., 1997). In addition, learners experiencing orphanhood may be at greater risk of emotional problems than other learners. Therefore, teachers who are not sensitized to the personal, social, emotional, and behavioral problems their learners may experience, as suggested in this study, are not well placed to identify the learners' nonacademic problems (Best, 2007). Such teachers are more likely to be unprepared or unwilling to provide pastoral care.

"Pastoral care" is a term that can be interpreted in a variety of ways depending on the ethos of the school (Cleave et al., 1997). In some schools it is the responsibility of the entire staff, while in others it is the responsibility of a group of pastoral specialists. This study's findings concur with the argument of Cleave and others (1997) and suggests that in the context of orphaned learners, although it may seem almost certainly impractical for teachers to meet some of the orphans' needs in the absence of alternative sources of support such as social services, it may be necessary for teachers to acquire knowledge of and skills in the pastoral role. The teachers' accounts reveal the need for 
counseling in cases of behavioral problems that may be triggered by the orphans' emotional state, or in cases of abuse such as the rape reported by one of the teachers. Although some of the learners may be in need of professional help, as alluded to by the teachers, others may benefit from the support given by teachers competent in providing pastoral care.

The current situation in some schools, as described by the teachers, means that they need to take on multiple roles if they are to meet the material, social, and emotional needs of the learners. The need to take on multiple roles makes it necessary to redefine teachers' roles in a shift from dispensing knowledge to counseling and pastoral care in order for the learners to gain maximum benefit from their educational experience. It would seem that there is a call for teachers to adapt to these new roles. The issue that needs to be addressed is the interpretation of the concept of pastoral care.

In this study, teachers' interpretation of the role of care lacked clear and shared understanding. The literature reveals that pastoral care means different things to different school systems and may include teachers' role in guidance and counseling, spiritual guidance, or a bureaucratic structure of an education institution (Best, 1977; Chittenden, 1999; Watkins, 1999). Evans (2002) advocates for teacher development that focuses on redefining and modifying the role of teachers to include caring for social and emotional needs. Although the need for skills development did not emerge directly from the teachers' interviews in this study, in a similar study on educational opportunities for orphaned learners, some teachers expressed the need to be trained in counseling (Oleke et al., 2007). These researchers further suggest the need for teachers to acquire specialized skills if they are to provide effective emotional and social support for learners. Moreover, not all schools have trained guidance and counseling teachers, and not all learners are likely to require professional help. There may be cases where teachers who are competent in pastoral care, and who have the enthusiasm, could assist the learner under stress without referring him or her to a specialist.

The findings of this study reveal that teachers' responses to orphaned learners' needs seem to be influenced by their perception of their roles. Not all the teachers regarded pastoral care as being part of their responsibilities. Teachers who empathize with the or- phaned learners tend to assume the care-giving role and respond by providing material and sometimes emotional support. The teachers who provided support explained that their motivation to help the learners was based on their background experience and religious belief. Their motivation is based on their background experience and religious beliefs; but there were those who refer the learners to other teachers for support. Although some of these teachers strive to provide the orphans with food, clothes, and, at times, emotional support, their narratives suggest a heavy workload.

In this study, it appears that the burden of supporting these learners also seems to be linked to the absence of supportive leadership. The teachers' accounts of support or lack thereof from school leadership and management reveal a need for leadership involvement in the initiatives and a systematic structured approach to providing for the learners' needs. The results of this study indicate that school leadership needs to be more sensitive to the needs of orphaned learners, and school leaders also need to be part of the whole support initiative in order for the teachers' efforts to be more successful and less strenuous, as described by one of the teachers. It may mean that school leaders' engagement with the activities geared to supporting the orphans could enhance the teachers' capacity to provide pastoral care and to involve other stakeholders. One of the dilemmas mentioned by the teachers interviewed was the use of her time, which created conflict about what should be given prioritythat is, teaching the learners or preparing their lunch. What seems to emerge from the teachers' responses to questions about their commitment is that teachers would always be confronted with orphans in their classes and would never fully escape the responsibility of helping them. In this context, it is important to consider the following questions: Do teachers have the capacity to provide pastoral care and what would help them to do their work better?

This study focused on the experiences of five teachers. Because of the limited sample, the findings of this study cannot be generalized beyond the context of the field of study. However, the description of the context of this study may enable readers to determine the transferability of the findings to their own setting (Seale, 2000). Another limitation is the use of interviews as the only data collection method. The data 
collected from the interviews could not be triangulated by other methods such as document analysis and observation. The absence of other sources of data, such as a response of support from the school principal or social workers, made it impossible to substantiate some of the findings from the interviews. Contextual factors likes poverty, which was not explored in the study, could have also influenced the way teachers responded or did not respond in providing for the needs of the learners. Despite the limitations, the emerging themes from the context of this study could contribute to understanding how teachers cope with the responsibility of providing care to orphaned learners in some schools. Further research needs to be done with a larger sample and multiple data sources to shed more light on this topic

\section{Conclusion}

The results of this study provide some insights into the experiences of teachers in two schools with orphaned learners in South Africa and the changing role of the teachers, leadership and management implications for the schools. It was evident from this study that some teachers are involved in some kind of pastoral caregiving activities in response to the needs of orphaned learners. Some teachers responded by providing for material needs and giving emotional support, while others referred the orphaned learners to other teachers for assistance. This is clearly a move away from the traditional role of imparting knowledge to the learners to an additional new role of providing social and emotional support for the learners, as well as counseling and pastoral care (Zappulla, 1997, De Witt \& Lessing, 2005; Best, 2007; Robson \& Kanyanta, 2007). The teachers who opted to provide care for the orphaned learners seem to be struggling to meet the learners' needs in the absence of material and human resource support. This finding calls for an urgent need to redefine the role of teachers with an emphasis on care giving. It also suggests that pre-service programs and inservice teacher development training programs should include preparing teachers to provide pastoral care to increase their potential for supporting grieving children. Such programs are likely to empower and develop the teachers' care-giving competencies and skills in providing care for orphaned learners (Evans, 2002). This study found that some teachers provided for the material needs of the orphaned learners from their own resources and other sources. If more teachers could be involved as caregivers and work as a team to solicit material resources, then it would ease some of the burden of providing for the orphaned learners as described in this study.

In light of the teachers' perception of school principals' involvement in supporting orphaned learners in this study, it would seem that leadership in schools that aims at encouraging and supporting teachers to support their learners is crucial if teachers are to fulfill the material, emotional, and social needs of the learners. At present, the teachers seem uncertain of their responsibilities in terms of care giving. This study shows that teachers expect the school principal to support them in providing for the needs of the learners. In order for the school principals to meet teachers' expectations there is a need for training on strategies and new ways of management that embrace motivation, the provision of resources, and other forms of support for the teachers' efforts to provide pastoral care (Cleave et al., 1997).

The teachers also acknowledged that, given the situation in their schools, the state should consider employing full-time and part-time social workers and counselors to support these learners, which would relieve the teachers of some of their multiple layers of responsibilities. However, more research needs to be done on the role of leadership in providing pastoral care and possible partnership relationships that could be established between social workers and counselors with the teachers in playing the different but interdependent roles in supporting orphaned learners, and probably other learners in vulnerable situations.

\section{References}

Abebe, T. \& Aase, A. (2007). Children, AIDS and politics of orphans care in Ethiopia: The extended family revisited. Social Science \& Medicine, 64, 20582069.

Beard, B. J. (2005). Orphan care in Malawi: Current practices. Journal of Nursing, 22(2), 105-115.

Berger, E. H. (2000). Parents as partners in education (5th ed). Upper Saddle River, NJ: Prentice-Hall, Pearson Education. 
Best, R. (2007). The whole child matters: The challenge of Every Child Matters for pastoral care. Education 3-13, 35(3), 249-259.

Chitiyo, M., Changara, D. M., \& Chitiyo, G. (2008). Providing psychological support to special needs children: A case of orphans and vulnerable children in Zimbabwe. International Journal of Education Development, 28, 384-392.

Chittenden, A. (1999). Teachers as carers: A case study of a secondary school's pastoral process. Pastoral Care in Education, 17(2), 14-22.

Cleave, H., Carey, P., Norris, P., Sloper, P., While, D. \& Charlton, A. (1997). Pastoral care in initial teacher education: A survey of secondary teacher education institutions. Pastoral Care in Education, 15(2), 1621.

Cluver, L. \& Gardner, F. (2007). Risk and protective factors for psychological well-being of children orphaned by AIDS in Cape Town: A qualitative study of children and caregivers' perspectives. AIDS Care, 19(3), 318-325.

De Witt, M. W. \& Lessing, A. C. (2005). Educators' views on the needs and support of HIV/AIDS orphans in their psychological development. Journal of Child and Adolescent Mental Health, 17(1), 1322.

Department of Education. (2007). The National Policy Framework for Education and Development in South Africa: More teachers: better teachers. Pretoria: Government Printers.

Department of Education. (2000). Norms and Standards for Educators. Government Gazette, 243 (21565), 22 September.

Dowdney, L. (2000). Annotation: childhood bereavement following parental death. Child Psychology and Psychiatry, 41(17), 819-830.

Epstein, J. (2001). School, family and community partnership: preparing and improving schools. Oxford USA: Westview.

Evans, L. (2002). What is teacher development? OXford Review of Education, 28(1), 123-137.

Foster, G. \& Williamson, J. (2000). A review of literature of the impact of HIV/AIDS on children in subSaharan Africa. AIDS, 14(3), 275-284.

Freeman, M. \& Nkomo, N. (2006). Guardianship of orphans and vulnerable children: A survey of current and prospective South African caregivers. AIDS Care, 18(4), 302-310.
Giese, S., Meintjes, H., Croke, R., \& Chamberlain, R. (2003). The role of schools in addressing the needs of children made vulnerable in the context of HIV/AIDS. University of Cape Town: Children's Institute.

Heymann, J., Earle, A., Rajaraman, D., Miller, C., \& Bogen, K. (2007). Extended family caring for children orphaned by AIDS: Balancing essential work and caregiving in high prevalence nations. AIDS Care, 19(3), 337-345.

Jarolimek, J., Foster, C. D., \& Kellough, R. D. (2001). Teaching and learning in the elementary school (7th ed). Upper Saddle, NJ: Merrill Prentice Hall.

Kidman. R., Petrow, S. E., \& Heymann, S. J. (2007). Africa's orphan crisis: Two community-based models of care. AIDS Care 9(3), 326.

Loots, T. \& Mnguni, M. (2006). Pastoral support competencies of educators subsequent to memory box making: Part of asset-based research project on school-based support. Unpublished paper, University of Pretoria: South Africa.

Makame, V., Ani, C., \& Grantham-McGregory, S. (2002). Psychological well-being of orphans in Dar Es Salaam, Tanzania. Acta Paediatrica, 91(5), 459465.

McBride, R. (2002). Playing down presence: The importance of in-depth research for education for development. In M. Schweisfurth, L. Davis, L \& C. Harber (Eds), Learning democracy and citizenship: International experiences. United Kingdom: Symposium Books.

Miller, R. (1990). What are schools for? Holistic education in American culture. Brandon, Vermont: Holistic Education Press.

Nyambedha, E. O., Wandibba, S., \& Aagaard-Hansen, J. (2003). Changing patterns of orphaned care due to the HIV epidemic in Western Kenya. Social Science \& Medicine, 57, 301-311.

Oleke, C., Blystad, A., Fylkesnes, K., \& Tumwine, J. K. (2007). Constraints to the educational needs of orphans: A community-based study from northern Uganda. AIDS Care, 19(3), 361-368.

Richter, L. (2003). The impact of HIV/AIDS on the development of children. Paper presented at the Institute of Security Studies Seminar - HIV/AIDS vulnerability and children: Dynamics and longterm implications for South Africa. Pretoria, 4 April 2003. 
Robson, S. \& Kanyanta, S.B. (2007). Moving towards inclusive education policies and practices? Basic education for AIDS orphans and other vulnerable children in Zambia. International Journal of Inclusive Education, 11(4), 417-430.

Robson, S. \& Sylvester, K. B. 2007. Orphans and vulnerable children in Zambia: The impact of HIV/AIDS epidemic on the basic education for children at risk. Educational Research, 49(3), 259272.

Schierhout, G., Kinghorn, A., Govender, R., Mungani, J., \& Morely, P. (2004). Quantifying effects of illness and death on education at school level: Implications for HIV/AIDS responses. Final report submitted to the Joint Centre for Political and Economic Studies. Health and Development Africa.

SCOPE-OVC/Zambia. (2003). Findings of orphans and vulnerable children psychological survey. USAID/Zambia: Family Health International.

Seale, C. (2000). The quality of qualitative research. London: Sage Publications.

South Africa HIV \& AIDS statistics summary. Available online at: http://www.avert.org/safricastats.htm [Retrieved October 29, 2007].

State of the environment in South Africa. Mpumalanga poverty and vulnerability. Available online at: http://www.mpu.agric.za/SOER/Mpumalanga [Retrieved November 2, 2007].

Taylor, M. \& Kvalsvig, J. D. (2008). Scaling up support for children in HIV-affected families by involving early childhood development workers: Community views from Kwazulu-Natal South Africa. Development South Africa. 25(1), 61-73.

Thurman, T. R., Snider, L. A., Boris, N. W., Nyirazinyoye, L., \& Brown, L. (2008). Barriers to the community support to orphans and vulnerable youth in Rwanda. Social Science \& Medicine, 66, 15571567.

UNAIDS Inter-agency Task Team on Education and HIV/AIDS. (2004). The role of education in the protection, care and support of orphans and vulnerable children living in a world of HIV and AIDS. Available online at:

http://portal.unesco.org/en/ev.php [Retrieved October 25, 2007].
Urassa, M., Boerma, T., Ng'weshemi, J. Z. L., Isingo, R., Schapink, D., \& Kumogola, L. (1997). Orphanhood, child fostering and the AIDS epidemic in rural Tanzania. Health Transition Review Supplement, $7(2), 141-153$.

USAID (2000). Efforts to address the needs of children affected by HIV/AIDS. Report to Congress: An overview of USAIDS development programmes and approaches. The Synergy Project. Available online at: http://wwwsynergyaids.com [Retrieved August $12,2006]$.

USAID (2001). Responding to the educational needs of children and adolescents affected by AIDS in subSaharan Africa. Report on Town Hall Meeting, October 23, 2001. Available online at: http://www.synergyaids.com [Retrieved May 5, 2006].

Van Wyk, N. \& Lemmer, E. (2007). Redefining homeschool community partnership in South Africa in the context of HIV/AIDS pandemic. South African Journal of Education, 27(2), 301-316.

Watkins, C. (1999). The case of restructuring the UK secondary school. Pastoral Care in Education, $17(4), 3-10$.

Willis, C.A. (2002). The grieving process of children: Strategies for understanding, educating and reconciling children's perception of death. Early Childhood Education Journal, 29(4), 221-226.

Zappulla, C. (1997). Suffering in silence: Educators with Aids and the moral school community. New York: Peter Lang.

IJEPL is a joint publication of the Association for Supervision and Curriculum Development, the Faculty of Education at Simon Fraser University, and the College of Education and Human Development at George Mason University. By virtue of their appearance in this open access journal, articles are free to use, with proper attribution, in educational and other non-commercial settings 90 days after initial publication. Copyright for articles published in IJEPL is retained by the authors. More information is available on the IJEPL Web site: http://www.ijepl.org 